DOI https://doi.org/10.36059/978-966-397-201-5/1-19

\title{
TIME AND MODERNITY AS CATEGORIES OF MUSICOLOGY: HISTORICAL AND SEMIOLOGICAL PARADIGM
}

\section{Samoilenko A. I.}

\section{INTRODUCTION}

The category of time accompanies musicology at all its cognitive levels: axiological cultural and semantic, praxeological genre, musical and style textological, and finally in linguistic - as at the level of deep generative poetics of music. So, they replace one another with the forms of temporal representations that form a sequence of epistems - cognitive adjustments: "cultural time", genre time as a certain historical time of music, stylistic time as a figurative and symbolic ideational, triggering conceptualization mechanism, as well as compositional time as adjacent between the previous style and the next, linguistic, levels; the latter acts as the time and place of the direct creation and performance of a musical composition.

Through compositional time - the ways of organizing it, that is, on the border of the style and symbolic and stylistic circles, the concept of modernity acquires relevance and concretization - precisely in connection with the immanent logo of music, that is, in a conceptually "pure" and absolute meaning, like what is created in the chronologically immediate context and often still does not have completely clear, defined genre and style indicators, therefore, it requires direct comprehension of the musical text qualities - mastering, evaluations, literal presence of it; that means, analytical penetration into the musical material.

But it should be remembered that each historical epoch had this - its own - immediate modernity; so, it should be remembered that modernity is a kind of historical situation. Therefore, when referring to distant chronological musical and historical phenomena, evidence is so valuable and necessary (direct witnesses are important) in the form of listeners' reviews, critical notes, research papers, memoirs, etc.

The interaction of the value experience of music and the possibility of its semantic preservation - reconstruction, its interpretative reorganization is due to the artistic and semantic nature of time in music, that is, features of the phenomenon of musical time, growing on a 
specific linguistic basis. This phenomenon requires special study criteria, primarily the development of a historical and semiological approach.

\section{Historical knowledge of time}

Man learns from history; history, since this is the history of mankind, «learns» from man. Behind this rhetorical expression there lies the drama of a person's relationship with the time scales of life. It is a very common opinion that history has not taught anyone anything yet ... However, can we trust it?

If we compare the generic cumulative humanity with a holistic living organism, then historical knowledge appears to be its nervous system, which permeates all parts of the body, stimulates the activity of all organs and transmits signals from them to the central control organ - the brain, the functions of which in the structure of historical knowledge are assumed by its methodology. The most essential in the methodology is the clarification of the appropriateness of knowledge, that is, the answer to the question of where it leads to and what it exists for.

There is well known Plato's thought that correctly posed questions is half the training, that is, half the answer to them. Therefore, we will try to identify those derivative questions that arise when trying to answer the main methodological question about the modern significance of historical knowledge in its involvement in ideas about the humanitarian culture and its spatial and temporal coordinates - chronotopic dimensions. This also means finding the necessary and sufficient number of such questions, determining their order and categorical weight. Today, there is a need to create a dictionary of the modern historian as a broad-based humanitarian, not indifferent to the issues of the artistic functioning of culture, as an important aspect of its self-determination in the course of history. From the side of the history of art, in particular the history of music, there are significant clues regarding the true content and purpose of historical processes in their inseparability from the existence of culture, from the existence of the human person. It is no coincidence that really large historians have not passed questions about the artistic creation and personalities of artists.

Connected with the study of special artistic and creative matter, a musicologist can come closer than other art critics to the deep semantic content of human history - the phenomenon of humanity, which from the time of Confucius to the era of Bakhtin appears to be a true "factor X" in the historical evolution of man. 
The Greek word "history", which, according to V. Dahl, has long been accepted by all European languages, is interpreted as a story about events or adventures, a description of the life and circumstances of a people's life ${ }^{1}$. That means, it immediately indicates the use of the word as the main tool for historical reflection of the world, associated with the development of rational and logical forms of reality awareness; it appeals to the cognitive abilities of man, to the «space of knowledge». The word (verbal logo form) is quickly turning from an auxiliary tool into the main subject of historical cognition, a factor in the formation of the textual memory of the human community, bringing history and historiography closer to identification. The second feature of historical knowledge, which also manifests itself very early, is its breadth, providing comparison - a comparative approach, the ability to differentiate objects of historical study, but in order to identify their common significance. The extreme breadth of history and its striving for universal indicators of being is evidenced by the definition of R. Wipper: "We call history the science of the fate of the human race on earth. For this science it is easy to collect a lot of information about the times closest to ours. In an enlightened society, they are worried that there remains a memory of what has been experienced, they keep records of events and human orders. But the farther we go back in past centuries, the less such concerns, the fewer records we will meet" 2 . These words make three typical signs of historical knowledge visible, which can be attributed to the characteristics of historical reality: reliance on the real, actual, on people's lives; the use of written evidence of this life, factography because of the inability for the historian to be present directly in the past; the special importance of ancient sources and confirmation of their authenticity.

The paradoxical duality of history as a subject area of knowledge lies in the fact that its main reality is the existence of the human community in time, which forms its own course of history; but this reality arises in the displayed form - with the help of the conventionality of the verbal description, conditional content structures of texts that can be attributed to the primary sources. The foregoing explains why V. Klyuchevsky offers a "double" definition of history: as a movement in time, a process;

${ }^{1}$ Даль В. Толковый словарь живого великорусского языка. В 4-х тт. Т 2. М.: ОЛМА Медиа Групп, 2007. С. 54.

${ }^{2}$ Виппер Р. История древнего мира. В. Ю. Виппер. История древнего мира; А.А. Васильев. История средних веков. М.: Изд-во «Республика», 1993. С. 14. 
as process knowledge. In addition to the emphasis on the concept of time, as a key one, the Russian historian puts forward the concept of «human society», as reflecting the "content of history»; in his opinion, history, as a separate science, a special area of scientific knowledge should be studied, serves the historical process, that is, the course, conditions and achievements of human society or the «life of mankind» in its development and results» ${ }^{3}$.

V. Klyuchevsky creates a special theoretical concept of historical knowledge, at the center of which he places a person, but as a cultural collective being, so, in his interdependence with the properties and actions of the forces organizing the historical process, they are his "kinetics". It is this "man-science" side of Klyuchevsky's historical doctrine that forces him to ask the question about "the secret of the historical process" associated with the "energy of people development", acting on the basis of "communication and continuity" as a means of human community. The importance of the human factor in history also persists when Klyuchevsky reflects on the necessary factors for the emergence of community between people: "This is common under two conditions: that people understand each other and that they need each other... These conditions are formed by two common abilities: the mind that acts according to the same laws of thinking and by virtue of the general need for knowledge, and the will that causes actions to satisfy needs... Time consolidates the digestible heritage with a new moral connection, historical tradition...» ${ }^{4}$. We add that under the will the historian understood the psychological principle that reveals the human individuality and its personal purpose. Thus, the psychological properties of the human individual, the semantic needs of the individual, also become conditions and factors of historical time.

Therefore, the subject area of historical knowledge includes understanding, mind, will, as purely human properties that acquire a generalized - general historical - sense and determine those processes of communication and transmission of accumulated experience in which the special creative energy of the human community historical movement accumulates and manifests itself in time. The "objectivity" of the historical process thus turns around to be recognizing the driving force of

${ }^{3}$ Ключевский В. Лекции по русской истории. В. Ключевский. Собрание сочинений в 8-ми тm. Т.1. М.: Гос. изд-во полит. лит-ры, 1956. С. 14.

4 Ключевский В. Лекции по русской истории. В. Ключевский. Собрание сочинений в 8-ми тm. Т.1. М.: Гос. изд-во полит. лит-ры, 1956. С. 19, 21-22. 
the history subjects, as well as the subjective human consciousness. V. Klyuchevsky, who, incidentally, is considered as one of the most objective Russian historians, surprisingly predicts the theory of passionarity of L. Gumilev, who considered the presence of a special kind of energy (passionarity) to be the cause of ethnogenesis and changes in the ethnic development of mankind. But the main thing in Klyuchevsky's conception is that he, firstly, proves that historical knowledge does not exist and is not essential outside a person; secondly, it discovers that in unity with the knowledge of history its understanding develops, manifests itself, and this opens up the need to study historical human psychology, significant historical figures; thirdly, it expands the idea of the factual basis of historical knowledge, allowing to introduce artifacts to it - substantive evidence of the creative historically moving energy of a person, in connection with which not only verbal, but also other artistic and iconic monuments of the past and present can claim the role of "historical witnesses", conditional historical texts.

As far as subject of history to our knowledge (cognition) is conditional, then conditional semiotic ways of creating and storing, transmitting historical reality, that semantic content of the conditional culture world, the artistic world of art, which are associated with the human ability to understand and interpret, acquire a new methodological value. Therefore, S. Averintsev finds in the symbolic structures, which are inherent in a particular culture, its main historical content; he calls it "the algebra of the history of culture", noting that "the history of culture is in its essential part the history of human symbolism". In his central work "Poetics of Early Byzantine Literature", he deduces the order of history from a system of ideas about space and time. That means, he offers, inheriting in a certain sense M. Bakhtin's positions, worldview chronotopic dimensions of the historical process, deepening the understanding approach of historical knowledge ${ }^{6}$.

Thus, the symbolic conventions of culture, which affects artistic forms and artistic consciousness, determine the main historical realities, artifacts - primary evidence, connects the "written" (subject and material) with "oral" (ideational) sides of the historical process. Moreover, as directly "understanding", the oral side of historical memory

5 Аверинцев С. К уяснению смысла надписи над конхой центральной апсиды Софии Киевской. С.С. Аверінщев. Софія-Логос. Словник. К.: Дух і література, 1999. С. 214.

${ }^{6}$ Аверинцев С. Поэтика ранневизантийской литературы. М.: «Сoda», 1997. 
is deeper and more socialized; it indicates the fundamental basis of historical consciousness.

When we talk about the "oralness" of history, we mean, first of all, not only the oral verbal plan of culture, but also the whole totality of extra-symbolic forms, forms of artistic creativity; and secondly, the semantic content of the historical process that remains outside opportunities of well-known iconic structures, but interacts with them as a phenomenon of deep cultural memory - the collective unconscious. Actually, it is to this plan of social memory that the historical and cultural theory of $\mathrm{O}$. Spengler, tinted by art history, is addressed, as well as the autobiographical concept of the history of N. Berdyaev. Spengler defines world history as "some spiritual opportunity," "some expression of the form sense," as "the image by which a person's imagination wants to gain an understanding of the world living being in relation to his own life and thus provide it with an in-depth reality" ". In his interpretation of the history mechanism, the psychological abilities of human consciousness - imagination, understanding, feeling and experience also turn out to be tools of knowledge.

N. Berdyaev represents the historical process as already fully personified and individually psychologized, revealed in a dramatic clash with personal will: "I survived the world, the entire world and historical process, all the events of my time as part of my microcosm, as my spiritual path ... <.. > .. I had to live in a catastrophic time both for my homeland and for the whole world. In my eyes whole worlds collapsed and new ones arose. I could observe the extreme inconstancy of human destinies ...<... ... History does not spare the human personality and does not even notice it» ${ }^{8}$. Today we know that history "noticed" Berdyaev, who was included in the list of the most prominent thinkers of the first half of the XX century.

Understanding the historical process as a human "act by life" (M. Bakhtin) not only strengthens and deepens the psychological criteria of historical knowledge, but also allows to propose the nomination "homo istoric" - "historical man" (that N. Berdyaev was, in particular), thereby recognizing human authorship in history and the dependence of

${ }^{7}$ Шпенглер О. Закат Европы: Очерки морфологии мировой истории. Т. 1 Образ и действительность. Пер. с немецкого Н.Ф. Гарелин. Мн.: ООО Пупурри, 1998. C. $20 ; 10$.

${ }^{8}$ Бердяев Н. Самопознание. Сочинения. - М.: ЗАО Изд-во ЭКСМО-Пресс; Харьков: Изд-во Фолио, 1999. С. 252-253. 
personality being in time on the general state of temporary consciousness of culture, on its chronos.

Trying to take into account and combine all the factors and forms of the historical process, suggesting its semantic attitudes, and also identifying personal needs for historical self-determination, recognition, today's historical knowledge is increasingly turning into historiology of culture aimed at determining the theoretical principles of the temporal and spatial dimensions of history, including - at the study of art chronotopes. According to M. Bakhtin, it is they who form the "gateway to meaning". That is why, attention to them contributes to the development of an understanding tendency of humanitarian knowledge, allows to combine quantitative and qualitative factors, indicators of historical thinking'.

Chronology, with its meticulous and rigorous relationship to dates and the digital timing of history, not only remains a necessary component of historical memory; it requires the special ability of the historian researcher to reproduce the order of events and facts, to feel the "aesthetic correctness" of this order, special historical imagination, which manifests itself in working with numbers (numerical indicators). Interesting and accurate are the comments on this subject by R. Wipper, who, in particular, writes: "Chronological memory forms a rare special ability: with respect to the vast majority of students, teaching chronology is a completely useless exercise" 10 . Precisely because chronology teaches the historical temporal order, it needs an arrangement and ordering of dates, related events, facts, names in the conditional space of culture, which appears to be nothing more than a space of human activity and creative self-fulfillment, that is, a space of human actions - as an expression of responsibility for life, for human behavior and the implementation of certain ethical principles that are indicative of a given historical type of culture.

If chronology recreates the immanent logos of history (immanent, but laid down in it by subjective human efforts to master being), then the study of the spatial coordinates of cultural life (ethnic interethnic, social transpersonal, psychological immanent-personal, in the end - artistic

9 Бахтин М. Формы времени и хронотопа в романе. M. Бахтин. Bonpocbl литературь и эстетики. Исследования разных лет. М.: Художественная литература, 1975. С. 234-407

${ }^{10}$ Виппер Р. История древнего мира. В. Ю. Виппер. История древнего мира; А.А. Васильев. История средних веков. М.: Изд-во «Республика», 1993. С. 12. 
interspecific, intergeneric, interstyle), so to say, the spatiology of culture allows us to objectify the components of the historical logos, to find the symbolic functions of the historical world order, to recreate ethos and pathos of history.

In this regard, musical art turns out to be that mirror of historical knowledge (mirror reproduction of historical reality), which is more pleasant and useful for a person to look into than any other... Therefore, it can be considered that musicology can provide significant chronotopic support to historiology, which means - support in the main question of the appropriateness of historical knowledge - the sense of history.

This question, or rather, the search for a system of answers to it, needs to define such a dictionary of historical categories that would meet the interests of modern humanities, including musicologists. Presumably, it contains three groups of categories, of which the first indicates the objective content of historical knowledge, the second indicates the forms and tools of its translation, and the third indicates methods of development, respectively, the appropriateness of historical knowledge.

The first group includes the following categories:

the course (movement) of history - historical reality;

knowledge of history - understanding of history;

historical convention and conditional history;

historical sources, first evidence;

oral and written history.

The second group includes categories such as:

historical consciousness and imagination;

homo istoric - historical man;

historical time - the time of history (chronology - periodization, quantitative and qualitative indicators of historical time);

historical chronotopes.

The third group consists of the following categories:

historical memory, historical thinking;

the history of culture - the history of personality;

the history of psychological knowledge - the history of human consciousness (of higher psychological functions);

the sense of history.

The sense of history (its true sense) on the part of an individual person is the reproduction of the beauty of time in personal consciousness, the aesthetic transformation of human memory, which is included in the memory of culture with special structures; it harmonizes 
its space, provides it with the beauty of humanity. From the side of history - the historical state of culture - this is an increase in the value of an individual person life and of the human community as a whole - the human «common life», the increment of the general human mind, the strengthening and ennobling of individual manifestations of will.

\section{Modernity as a form of interpretative time and the language of music}

The spectrum of phenomena that the concept of modernity embraces is very wide. It involves the inclusion of such a phenomenon as the artistic time of culture, implying dialogicity in temporal and spatial relations. Today - and this is an attribute of the present modern to us the concept of modernity acquires an independent status of interpretative time - as a personality and psychological time of interpretation with its own semantic components and resonances.

The phenomenon of interpretative time combines the globalization of space and the mythologization of temporal attitudes, representations; it is included in all musical-creative and musical-reflective forms composer, performer, listener, musicology. It becomes indicative of that particular current historical situation, which today is most often defined as postmodernity - the postmodern state of culture and art. This situation presupposes an in-depth conceptualization associated with the separation of personalized and psychological time, with its individual-subjective symbolization (of course, typological features also appear in it, but this trend is not obvious, that is, it does not lie on the surface - it has not crystallized). Modern interpretative time can be considered as an analogy of the situation "Waiting for Godot"...", that is, as the effect of existential expectation - tension, requiring special semantic projections. The transformation of modernity concept into the neologism "postmodernity" is explained by the need to find a way out of this state of intense expectation, as an experience of temporary uncertainty, the loss of a temporal value center.

As A. Alferov rightly writes, "the modern historical situation will be replaced by some new situation. When this transition will happen, we do

${ }^{11}$ Напомним, что так называлась пьеса ирландского драматурга Сэмюэля Беккета, в английском варианте имеющая подзаголовок «трагикомедия в двух действиях». признанная самым влиятельным англоязычным драматургическим произведением XX века. 
not know, perhaps we have already entered it. What will it lead to, to whom and to what does the near future belong? V. M. Mezhuev rightly observes: "The situation of uncertainty created by this transition, as it were, equalizes everyone in the consciousness of their "non-modernity", makes us doubt the superiority of any identity, no matter who it is today", 12

These words of the modern culturologist reflect the main contradiction that arises when referring to the concept of modernity: the rapprochement of the categories of modern and historical, which hinders the clear identification, isolation of a segment of historical time as just and only modern; the inclusion of non-modern phenomena and representations, characteristics in the content of modernity, and most importantly - the lack of clear boundaries of time and space, the loss of a sense of temporal identity - a change in the very nature of this feeling leads to a profound transformation of temporal historical consciousness.

The concept of postmodernity significantly complicates the categorical position of the terms of time and modernity. As A. Matetskaya writes:

"The truth is no longer indisputable. They began to interpret it in the spirit of the practical needs of the institutions of society; ...the place of TRUTH is occupied by the "multitude of truths", and there is no longer any generally accepted way of choosing among the elements of this multitude. ... What should I do, how should a person of the post-modern era feel when the concept of truth has disappeared, when you can't be sure of anything and you can't know anything for sure? When many points of view coexist on equal terms, and no one can be sure of the correctness of the choice made... According to the theorists of postmodernism, a person simply "plays", enjoys life in all its diversity, since a post-modern society provides him with a huge amount of benefits and services. The man of postmodernity is much freer than people who lived in earlier eras. Freedom is manifested in everything: from the way of thinking and ways of expression to movements around the world and relations between the sexes. However, unlimited freedom of choice turns into freedom from oneself - a problem of identity crisis" ${ }^{\prime 13}$.

12 Алфёров А. Современность: два среза понятия. Информационный гуманитарный портал «Знание. Понимание. Умение». № 3. 2011.

13 Матецкая А. Социология культуры. Учебное пособие. Ростов-на-Дону: Феникс, 2006. С. 120-121 
The musical identification of historical time is a process of correlation and mutual objectification of representations of time and the iconic means of music, "spirit and letter", as a key antinomy of semantic reality of a person; it can be considered as a way to overcome the identity crisis, because it occurs in accordance with the antinomic rule of S. Averintsev (correlating the order of the cosmos - the order of history) as follows: the order of sense formation (understanding, style of worldview) determines the order of music, then its own internal order of knowledge about music is inevitably becoming historical and historically significant.

The words of St. Augustine testify most clearly to the connection of time and spirit: "Time exists only in our soul. The past is in the memory, the future is waiting...; the essence of the present tense is contemplation...; in you, my soul, I measure time. The impression of passing by remains in you, and it's something that now exists, I am measuring... I am measuring the impression (experience - A. S.), measuring time...; it seems to me that time is nothing but a stretch. But the extension of what exactly - I do not know with certainty, although it is unlikely that it would be anything other than the extension of the spirit itself" ${ }^{\prime 14}$. It is time that acts as the main existential of man and the human community; relations with time form deep "impressions" - experiences that are stored in memory.

Relations with time are modernity in its broadest sense, as an indication of sustainable ways of assigning and adapting, organizing and reorganizing time - ideas about time, and, therefore, time is conceptual.

The most familiar idea of the present - as the closest time dimension, the personality and individualized life parameter of the time process - is also the result of the conceptualization of time as the present (and, in Augustin's style, as the present present, present past and present future).

The cultural and aesthetic categorical significance of the concept of "modern" is determined by many factors. First of all, it points to a special artistic and aesthetic phenomenon, closely associated with attitudes and needs, the semantic dominants of modern culture. But it is not less addressed to those value realities of the cumulative human experience that have acquired the status of historical universals, that is, the premature - metatemporal - purpose. Also indicative of it is the

${ }^{14}$ См.: Таранов П. Анатомия мудрости: 120 философов: В 2-х томах. Симферополь: Реноме. 1997. Т. 1. С. 471. 
tendency to overcome the psychological cognitive and emotional crisis, in particular, the return to the interest in classical art forms, which can be seen as an attempt to update the «emotional matrices» of culture.

Consequently, from the general aesthetic and cultural side, the concept of modern, combined with the prefix "post", characterizes not so much the time of creation of the works as their socio-communicative status, as well as the performing side of musical creativity. So, for example, the repertoire that defines the performing practice of the opera house today is considered modern, regardless of the «age» of the opera works and even the degree of their staged novelty. In relation to musical theater, the category of (post) modernity becomes purely nominative and formal; its deeper artistic and aesthetic justification should not be sought in the general repertoire system, or even in directorial and production decisions, but in the combined image of an opera character - a true "hero of a work", a reference "hero of his time". The latter circumstance puts forward in the first row the criteria of the musical art present as an integral artistic and creative phenomenon, the figure of a performer, musician and artist.

However, the decisive criterion for the contemporary art of music, including the possibility of raising this concept into the meta-sphere of postculture, remains its linguistic matter, means of thinking and speech interpretation, that is, a specific musical logo.

As it was pointed out by Y. Kholopov, the musical logo is not being, but the secret of music. We say: the musical logo is both being and the secret of music. That means, it represents the secret immanent nature of music, which provides it with a unique sense-organizing role.

The existential basis of the musical logo is the "meeting" in music of three forms of time (as forms of musical comprehension and representation) - the historical "cultural time", personal psychological time and personal musical time - the immanent logic of the musical temporal process. Each of them contributes to the formation of musical content; the latter is an integrating and completing "effort" of the previous ones, translating them to the level of "musical thought".

The concept of Y. Kholopov ${ }^{15}$, who draws attention to particular dynamism in the development of European music of recent decades and

15 Холопов Ю. Изменяющееся и неизменное в эволюции музыкального мышления. Проблемы традиции и новаторства в современной музыке. М.: Сов. композитор, 1982. С. 52-104. 
offers a periodization of the history of European music from the point of view of the most important updates occurring in it, focuses on this interaction mainly in its substantive content (noting the beginning of the XI century as key temporal points - the work of Guido Aretinsky; the beginning of the XIV century - the work of Philip da Vitry; the beginning of the XVII century - the creative innovations of Giulio Caccini and the beginning of the XX century, marked by heuristics of Anton Webern).

According to Y. Kholopov, "accelerated updates are inherent in musical history. It is no coincidence that the Middle Ages and the Renaissance are often combined into one whole; but they cannot unite with each other the Renaissance and the New Time (1600-1900). Inside the XX century, both halves of the century are already sharply different. The swift evolution of musical thinking in our era is a universally recognized fact that does not need proof. All the music of the $\mathrm{XX}$ century seems to be a grand cataclysm, shaking the very foundations of traditional musical thinking. The adjacent short links in the long chain of changes are very similar to each other, the non-adjacent ones no longer seem to belong to the same chain..."

Regarding the category of modernity, without using the term itself, Kholopov quite accurately describes the prerequisites for the formation of this concept and its possible contradictions, when he notes that people of every time tend to experience especially acutely what is happening in front of their eyes, events that are close to them, whereas from a long temporal distance "everything looks very different: ars nova is difficult to distinguish from ars antiqua, Dufay's polyphony is included in a" strict letter "along with Palestrina's polyphony, and we may soon find it difficult to distinguish between the harmony sound of Berg and Rachmaninov». But Kholopov is also looking for those "great breaks in musical history" that make it possible to identify the ontological connections of the musical language and the semantic intentions of cultural consciousness; he notes that at the modern, that is, at "our" stage of musical art development, the most important thing is the phenomenon of a musical composition, for which the following compositional laws are valid: "The presence of thought, the corresponding division and

16 Холопов Ю. Изменяющееся и неизменное в эволюции музыкального мышления. Проблемы традиции и новаторства в современной музыке. М.: Сов. композитор, 1982. С. 52-104. URL: http://www.kholopov.ru/izm/. 
subordination of parts, a certain... time of experiencing music, definite time distribution"; in connection with them, the high-altitude system (as the basis of the sound structure of the composition) and the rhythm acquire special logical functions, since it is they that force people to go deeper into the music, "inside" its semantic content ${ }^{17}$.

According to $\mathrm{Y}$. Kholopov, the entire musical composition is permeated by the relations of musical logic (correspondences, symmetries, proportions, dimension, proportionality), including rhythm, harmony, counterpoint, form, and "beauty as a reflection of numerical order penetrates the musical-sound whole from top to bottom, generalizing with the radiance of a beautiful whole image". The central postulate of the research by $\mathrm{Y}$. Kholopov provides for the following theoretical positions:

- the history of music is the logic deployment of sound relationships; it is "time-becoming logic" measured by "musical numbers";

- "musical numbers", where the musical interval is representative ( 1 = unison and octave, 2 = fifth and fourth, 3 = third and sixth, etc.), arise as "generalized structures of consciousness that objectively arise in the process of its historical evolution in connection with public life practice";

- meaningfully, "musical numbers" are "coefficients of the consciousness level"; they arise in the process of «all material and intellectual activity of man», but they also become creatively initiative principles. That means, they are capable of «acting» into the world around them, to transform it;

- the basis of «musical numbers», therefore, the logo of music, aesthetic ideas about the purpose of a person and his consciousness, his sense-generating properties; therefore, «each subsequent highest number is what could be called: a new man - and - a new ideal».

According to Kholopov's theory, the aesthetic center of the musical and historical evolution of consciousness is time objectification in music - investing temporary content in a certain sign form, therefore the aesthetic (semantic) center of music forms its chronotopic sign thesaurus.

17 Холопов Ю. Изменяющееся и неизменное в эволюции музыкального мышления. Проблемы традиции и новаторства в современной музыке. М.: Сов. композитор, 1982. С. 52-104. URL: http://www.kholopov.ru/izm/. 
Its main qualitative indicators are inseparable and non-merged, both in horizontal deployment and in the vertical volume of musical tissue - this is the basic law of a musical text sound device, which reached its utmost expression in the $\mathrm{XX}$ century in dodecaphony and pointillism; dodecaphony is focused on the absolutization of non-fusion, and sonoristics - on the totality and absoluteness of inseparability. The interaction and opposition of these principles determines the development of one's own matter of music - musical fabric, texture to the same extent that the assimilation of the united or the unity of differences is the principle of harmony, and the unification of the unmatched or the difference of the one is the principle of polyphony. There is a methodological similarity between these technological areas, but they are not symmetrical, because they have different goals - the first reveals the possibility of merging and the absolute merging; the second is the possibility of non-fusion and its regularity, importance. But both this and the other are related to the attitude to the temporal order of music, that is, to the order that music brings to the relationship of a person with time.

Therefore, V. Martynov is not quite right, when he writes that time is absent in Palestrina's music, since space is united and not divided, and space in Beethoven's compositions, due to its unlimitedness and continuity, ceased to play the formative role that it played in Bach: he essentially draws attention to various forms of musical and textual ordering of time - polyphonic and homophonic-harmonic ${ }^{18}$.

\section{CONCLUSIONS}

In general, the term "modern" is ambiguous, it is able to indicate several temporal dimensions: the historical time of music creation, that is, modernity for its author; modern readings of a musical composition, that is, the form of a historical dialogue with a musical concept; finally, the current state of the music art, including the creation of fundamentally new musical and linguistic resources of musical compositions and methods, forms of performance.

Thus, historical time and "modern" time show a coincidence, especially noticeable in musical form.

18 Мартынов В. Время и пространство как факторы музыкального формообразования. Психология художественного творчества. Минск: Харвест, 2003. С. 130-144. 
From the standpoint of semiology, musical time is constituted by the general time of culture as the assimilated experience of a person's relationship with time, the cultural and historical typology of temporal modality. But even more, it is determined by the relation of musical sound to sense, and sense to sounding (including its "non-sounding" structures, "weightiness", in the terminology of M. Arkadiev) form of music, representing a specific non-verbal form of musical thinking.

Time and sense in music have common dimensions - "deep structure" and "surface structure", if we use L. Hakobyan's approach to the rhythmic organization principles of music and its terminology. Moreover, the rhythm, which, thus, becomes the main essential characteristic of both time and sense, can be considered as the connecting link of the data of two dimensions. Therefore, the definition of "deep structure rhythm" proposed by Hakobyan is equally valid with respect to both (time and sense in music): "The rhythm of the deep structure should be understood as its characteristics that determines the time distribution of the paradigmatic and syntagmatic positions of the elements included in composition of the surface structure" ${ }^{\text {"I }}$. In addition, Hakobyan especially emphasizes that «the fundamental difference between the rhythm of the deep structure and the rhythm of the surface structure (that is, from the category "rhythm" in the more familiar sense...) is that the former is continuous, while the latter is discrete" 20 .

Consequently, the rhythm common to sense and time formation in music also turns out to be "visual" and "invisible, secretive"; installation and resulting moments rising «above» (or going far deeper) in relation to the given «surface» of the composition, at the same time, by this very «surface» - as a combination of textural and spatial techniques for presenting a musical text. In other words, rhythm, becoming musically pronounced, stands in solidarity with the spatial form, although it does not become it to the end - and precisely because of the determining role of the "deep" rhythmic sense.

It is no coincidence that A. Losev singled out immanent time factors that do not go over to the side of spatial conditions - rhythm, symmetry, metro-rhythmic accent - and called them necessary musical categories dialectically arising from the expressive element of "pure number", if the

19 Акопян Л. Анализ глубинной структуры музыкального текста. М.: Практика, 1995. С. 88.

${ }^{20}$ Там же. 
latter consistently distinguishes moving peace, self-identical distinction and individuality ${ }^{21}$. Taken at various levels, in different volumes of the composition, they express an autonomous temporal idea of music, and the temporal factors of the musical composition are elevated to the value of "higher order rhythm".

\section{SUMMARY}

The article explores the sense of the category of time and the concept of modernity derived from it in modern musicology, defines methodological levels and discursive forms due to various methods of studying the time phenomenon. The concept of postmodernity is considered as an actual humanitarian term characterizing the new relationship of a person with historical time; the temporal possibilities of musical art, due to its artistic and iconic nature, are analyzed.

The study of historical knowledge principles, representing the total time of human experience, allows us to substantiate the importance of the symbolic memory of culture as the basis of worldview chronotopic dimensions of the historical process, guarantees its semantic content. The symbolic conventions of culture are considered in connection with the semantic experience of music. It is proved that the possibilities of interpretative reorganization of time in music are due to its special artistic and semiological nature; the phenomenon of musical time grows on a specific linguistic basis, therefore, it suggests autonomous learning criteria.

The development of the historical and semiological approach allows us to develop the concepts of chronology and spatiology of culture as indicators of our own logos of history, to determine the role of musical art as a mirror of historical knowledge, to offer a system of musicological categories corresponding to this, indicating the subject content of historical knowledge; the forms and tools of its broadcast; the methods of development, respectively, the appropriateness of historical thinking in music.

The role of interpretative time in musical-creative and musicalreflexive forms is discussed; it is noted that the phenomena of modernity - postmodernity acquire a paradigmatic significance in musical art; they are associated with the musical language evolution. The

21 Лосев А. Музыка как предмет логики. А. Ф. Лосев. Форма. Стиль. Выражение. Сост. А.А. Тахо-Годи. М.: Мысль, 1995. С. 552-553. 
most productive musicological approaches to the temporal order of music are determined, the socio-communicative features of the modern post-modern position of musical art are examined, as well as the principles of sense and time formation in music, in particular the originality of the musical rhythm.

\section{REFERENCES}

1. Аверинцев С. К уяснению смысла надписи над конхой центральной апсиды Софии Киевской. С.С. Аверінщев. Софія-Логос. Словник. К.: Дух і література, 1999. С. 214-243.

2. Аверинцев С. Поэтика ранневизантийской литературы. М.: «Coda», 1997. $343 \mathrm{c}$.

3. Акопян Л. Анализ глубинной структуры музыкального текста. М.: Практика, 1995. 256 с.

4. Алфёров А. Современность: два среза понятия. Информационный гуманитарный портал «Знание. Понимание. Умение». №3. 2011. URL: http://zpu-journal.ru/ e-zpu/2011/3/Alferov_Modernity/

5. Бахтин М. К методологии гуманитарных наук. М. Бахтин. Эстетика словесного творчества. М.: Искусство, 1986. С. 381-393.

6. Бахтин М. К философии поступка. М. Бахтин. Работы 1920-х годов. К.: Наукова думка, 1994. С. 9-68.

7. Бахтин М. Формы времени и хронотопа в романе // Вопросы литературы и эстетики. Исследования разных лет. - М.: Художественная литература, 1975. - С. 234-407.

8. Бердяев Н. Самопознание. Сочинения. М.: ЗАО Изд-во ЭКСМО-Пресс; Харьков: Изд-во Фолио, 1999. 624 с.

9. Виппер Р. История древнего мира. В. Ю. Виппер. История древнего мира; А.А. Васильев. История средних веков. М.: Изд-во «Республика», 1993. С. 14-244.

10.Гессе Г. Игра в бисер. М.: Художественная литература, 1969. $418 \mathrm{c}$.

11.Даль В. Толковый словарь живого великорусского языка. В 4-х тт. Т 2. М.: ОЛМА Медиа Групп, 2007. 672 с.

12.Ключевский В. Лекции по русской истории. В. Ключевский. Собрание сочинений в 8-ми тm. Т.1. М.: Гос. изд-во полит. лит-ры, 1956. $328 \mathrm{c}$.

13.Лосев А. Музыка как предмет логики. А. Ф. Лосев. Форма. Стиль. Выражение. Сост. А.А. Тахо-Годи. М.: Мысль, 1995. C. 405-602. 
14. Мартынов В. Время и пространство как факторы музыкального формообразования. Психология художественного творчества. Минск: Харвест, 2003. С. 130-144.

15. Матецкая А. Социология культуры. Учебное пособие. Ростовна-Дону: Феникс, 2006. 260 с.

16.Самойленко А. Время или пространство музыки: полемические аспекты проблемы музыкальной темпорации. Київське музикознавство. Вып. 21. К., 2007. С. 11-27.

17. Соловьёв В. Сочинения: В 2-х тт. 2-е издание. Общ. ред. $u$ сост. А.В. Гулыга, А.Ф. Лосев. М.: Мысль, 1990. Т. 2. 822 с.

18. Таранов П. Анатомия мудрости: 120 философов: В 2-х томах. Симферополь: Реноме. 1997. Т. 1. 624 с.

19. Холопов Ю. Изменяющееся и неизменное в эволюции музыкального мышления. Проблемь традиции и новаторства в современной музыке. М.: Сов. композитор, 1982. С. 52-104. - URL: режим доступа: http://www.kholopov.ru/izm/

20.Шпенглер О. Закат Европы: Очерки морфологии мировой истории. Т.1 Образ и действительность. Пер. $c$ немеикого Н.Ф. Гарелин. Мн.: ООО Пупурри, 1998. 688 с.

\section{Information about the author:} Samoilenko A. I., Doctor of Arts, Professor, Vice-rector for Scientific Work, Odessa National A. V. Nezhdanova Academy of Music 63, Novoselskogo str., Odessa, 65023, Ukraine 